\title{
Chlamydia in canine or feline coronary arteriosclerotic lesions
}

\author{
Ivan C Sostaric-Zuckermann ${ }^{1}$, Nicole Borel ${ }^{2}$, Carmen Kaiser ${ }^{2}$, Zeljko Grabarevic ${ }^{1}$ and Andreas Pospischil ${ }^{2}$
}

\begin{abstract}
Background: There are numerous reports linking Chlamydia infection to human coronary atherosclerosis. However, there is a lack of data regarding this correlation in dogs and cats, and there are no reports investigating coronary arteriosclerosis and Chlamydia in these species. The aim of the present study was to examine whether there is a correlation between canine and feline spontaneous atherosclerosis or arteriosclerosis and the presence of Chlamydia. Archived histopathological samples of dogs $(n=16)$ and cats $(n=13)$ with findings of atherosclerosis or arteriosclerosis in heart tissue were examined for the presence of Chlamydiaceae using real-time PCR, ArrayTube Microarray and immunohistochemistry. Additionally, arteriosclerotic lesions of all cases were histologically classified and graded.
\end{abstract}

Results: Both canine atherosclerotic cases, and all 14 canine arteriosclerotic cases were negative for Chlamydia. Only one of the 13 arteriosclerotic feline cases was positive for Chlamydia by real-time PCR, revealing C. abortus by ArrayTube Microarray. To our knowledge, this is the first description of C. abortus in a cat. Overall, the type and grade of canine and feline arteriosclerotic lesions revealed similarities, and were predominantly moderate and hyperplastic.

Conclusions: These findings suggest that there is no obvious correlation between canine and feline coronary arteriosclerosis and the presence of Chlamydia. In order to draw final conclusions about the correlation between Chlamydia and canine atherosclerosis, examination of more samples is required.

\section{Background}

To date, cardiovascular disease [1] is the most prevalent cause of human mortality. Hardening of the vessels, generally denominated as "arteriosclerosis", represents one of the dominant pathological lesions involved. Most commonly, the lesion causing this hardening of the vessel walls is a formation of atherosclerotic plaques. This represents an accumulation of large amounts of lipoproteins, predominantly low density lipoproteins (LDLs) in the arterial wall, commonly called atherosclerosis. The etiology and pathogenesis of atherosclerosis seems to be quite complex and is still not completely understood. However, it was hypothesized that the initial lesion is an immunologically mediated inflammatory response by the host, presumably triggered or facilitated by certain infective agents [2]. The most extensively investigated

\footnotetext{
* Correspondence: n.borel@access.uzh.ch

${ }^{2}$ Institute for Veterinary Pathology, University of Zurich, Vetsuisse Faculty,

Winterthurerstrasse 268, CH-8057 Zurich, Switzerland

Full list of author information is available at the end of the article
}

infective agents linked with atherosclerosis include: Helicobacter pylori, herpesviruses and Chlamydia (C.) pneumoniae [2-5]. Association of C. pneumoniae infection and atherosclerosis has been established in many reports using a variety of methods, primarily serology, though detection of the organism in vascular lesions is also determined by isolation in culture, polymerase chain reaction (PCR), electron microscopy, enzyme immunoassay, immunohistochemistry, immunocytochemistry, Tissue Microarray and in situ hybridization [6-13]. Nevertheless, there is lack of concordance when comparing methods [14].

Incidence of atherosclerosis in dogs and cats is far less common than in humans, and is usually a sequela of other diseases, namely hypothyroidism, diabetes mellitus, hypercholesterolemia or hypertriglyceridemia [15]. However, it is still unclear whether atheromatous and/or any arteriosclerotic lesions in dogs and cats could be influenced by infectious pathogens, as described in humans. There is only one report associating chlamydial 
infection and atherosclerotic lesions in dogs, but none for cats [16]. There are no reports linking arteriosclerosis as a more widespread and general lesion with chlamydial infection. Dogs and cats, as common pets, usually reach a relatively high age and share the same living environment with humans. Equally importantly, they are also potential hosts for chlamydial species. Therefore it would seem logical to consider the possibility of chlamydial involvement in these vascular lesions.

The purpose of this study was to try to establish a correlation between any type of arteriosclerotic changes in hearts of dogs and cats and chlamydial infection. It is worth mentioning however, that the initial aim of this study was to try to establish a correlation between atherosclerotic lesions and chlamydial infection. Unfortunately, since the number of cases with atherosclerotic lesions was very low $(n=2)$, an archive search and study of cases pertaining to arteriosclerotic lesions was conducted.

\section{Methods}

\section{Number and selection of cases}

A search of the archives of the Institute of Veterinary Pathology in Zurich was conducted. A computer database was used to find all dog and cat postmortem cases dating from 1987 until mid-September 2010 having any description of arteriosclerotic and/or atherosclerotic lesions in heart tissues. Of the total 7,057 dog and 8,601 cat necropsies, there were 16 canine $(0.23 \%)$ and 13 $(0.15 \%)$ feline cases with a previous description of arteriosclerosis or atherosclerosis in heart tissue. The mean age of selected dogs and cats was 10.44 and 9.23 years, respectively. Of these 16 canine and 13 feline cases, only paraffin blocks whose hematoxylin and eosin (HE) slides were described to have some arteriosclerotic or atherosclerotic lesion were selected for further investigation.

\section{Preparation of HE slides and microscopic examination}

For each selected paraffin block, a corresponding HE stained slide was prepared according to routine standard methods. A histopathological examination of all microscopic slides was conducted, and a grade (score) given of the arteriosclerotic/atherosclerotic lesions for each heart or aorta. Lesions of coronary arteries in heart tissues were classified into one of the five following grades: mild, moderate, severe or a combination of contiguous e.g. mild to moderate and moderate to severe. Furthermore, using the general categorization and description of vessel wall hardening lesions, these were described for each organ as being of atherosclerotic, hyaline (also described as hypertrophic hyalinization or hyalinosis) or hyperplastic arteriosclerosis type $[17,18]$. Finally, the arterial and/or arteriolar lesions in each heart were examined for the presence of the following changes: visible lumen narrowing, vessel wall edema, thrombosis, and degeneration of leiomyocytes. In the determination of the previous, only hearts with a minimum of two arteries and/or arterioles affected with the change were regarded as positive findings.

\section{DNA extraction}

Sections $(40 \mu \mathrm{m})$ of formalin-fixed and paraffinembedded tissue samples were deparaffinized in xylene, centrifuged at $13,500 \times g$ for $5 \mathrm{~min}$ and the xylene was removed by repeated extraction with ethanol followed by a second centrifugation and the removal of ethanol. The pellet was treated overnight with proteinase $\mathrm{K}$ on a thermomixer $\left(55^{\circ} \mathrm{C}, 550 \mathrm{rpm}\right)$. The DNA was extracted using the DNeasy Blood and Tissue Kit (Qiagen, Hilden, Germany) according to the manufacturer's instructions.

\section{Chlamydiaceae real-time PCR}

The extracted DNA of all organ samples $(\mathrm{n}=45)$ was investigated on an ABI 7500 Fast real-time PCR system (Applied Biosystems, Foster City, CA, USA) using the 23S-based Chlamydiaceae family-specific real-time PCR described previously [19]. This method includes primers Ch23S-F (5'-CTGAAACCAGTAGCTTATAAG CGGT3'), Ch23S-R (5'-ACCTCGCCGTTTAACTTAACTCC$\left.3^{\prime}\right)$, and probe Ch23S-p (FAM-CTCATCA TGCAAAAGGCACGCCG-TAMRA) and an internal amplification control consisting of primers EGFP-1-F (5'-GACCACTACCAGCAGAACAC-3'), EGFP-10-R (3'CTTGTACAGCTCGTCCATGC-5') and probe EGFPHEX (HEX-AGCACCCAGTCCGCCCTGAGCABHQ1). A 111-bp product specific for members of the Chlamydiaceae is also produced as well as a 177-bp product for the internal amplification control. A final volume of $25 \mu \mathrm{l}$ for each tested sample was achieved by adding $2.5 \mu \mathrm{l}$ of extracted DNA to $22.5 \mu \mathrm{l}$ of $2 \mathrm{X}$ TaqMan ${ }^{\circledR}$ Fast Universal PCR Master Mix (Applied Biosystems) and a final concentration of $500 \mathrm{nM}$ of each primer and the probe (Microsynth, Balgach, Switzerland). The cycling program was started by an initial denaturation $\left(95^{\circ} \mathrm{C}, 20 \mathrm{sec}\right)$ followed by 45 cycles of denaturation and annealing $\left(95^{\circ} \mathrm{C}, 3 \mathrm{sec}\right.$ and $60^{\circ} \mathrm{C}, 30$ $\mathrm{sec})$, with an automatically calculated cycle threshold value. All samples were tested in duplicate. If the duplicates showed a Ct value of $<38$, the sample was considered positive and if the mean Ct value was $>38$, it was considered questionably positive.

\section{ArrayTube (AT) Microarray for species identification of Chlamydiaceae}

Samples that were positive or considered questionably positive by real-time PCR for Chlamydiaceae were further examined by the species-specific $23 \mathrm{~S}$ ArrayTube (AT) Microarray [20]. 
Immunohistochemistry (IHC)

The presence of the chlamydial antigen in paraffin sections was investigated on cases positive or considered questionably positive for Chlamydiaceae by real-time PCR $(\mathrm{n}=1)$ using a Chlamydiaceae family-specific mouse monoclonal antibody directed against the chlamydial lipopolysaccharide (LPS, Clone ACI-P, Progen, Heidelberg, Germany). A detection kit (Dako, K5003, Switzerland) was used according to the manufacturer's instructions for detection. After deparaffinization in xylene and rehydration through graded ethanol to water, the antigen retrieval was performed by 10 min enzyme digestion (Proteinase K, Dako, S2019, Switzerland). Endogenous peroxidase activity was inhibited with peroxidase-blocking solution for $5 \mathrm{~min}$ at room temperature, then slides were incubated for 60 min with the primary antibody diluted 1:200 in antibody diluent (S2022, Dako, Switzerland). The incubation with the link-antibody and the substrate solution was performed at RT for 10 min each, after which the slides were developed in a 3-amino, 9-ethyl-carbazole (AEC) substrate solution for $10 \mathrm{~min}$ and counterstained with hematoxylin. Negative controls of each section were performed using only the antibody diluent instead of the primary antibody. For the positive control, intestinal tissue from gnotobiotic piglets experimentally infected with porcine C. suis strain S45 were used [21].

\section{Results}

\section{Number and selection of cases}

Of dogs, 15 animals (93.8\%) had recorded lesions only in the heart $(\mathrm{n}=14)$ or aorta $(\mathrm{n}=1)$, while one animal (6.2\%) showed lesions in the heart and some additional organs (kidney and lungs). Of cats, seven animals (53.8\%) expressed arteriosclerotic lesions only in the heart, while the remaining six animals (46.2\%) had both coronary and non-coronary lesions (kidney, eyes, liver, brain, spleen, stomach).

\section{Microscopic evaluation and grading of the lesions Dogs}

Details of the 16 dogs are shown in Table 1. Only two cases had atherosclerotic lesions, while the remaining lesions were classified as arteriosclerosis $(\mathrm{n}=14)$.

Table 1 Type and grade of atherosclerotic and arteriosclerotic lesions in hearts and aorta of dogs $(n=16)$

\begin{tabular}{|c|c|c|c|c|c|c|c|c|}
\hline No & Breed & Sex & Age & Organ & Grade & Type & $\begin{array}{l}\text { Other organs } \\
\text { affected }\end{array}$ & $\begin{array}{l}\text { Concurrent lesions in the heart and other } \\
\text { organs }\end{array}$ \\
\hline 1 & Mongrel & M & 11 & Heart & $\begin{array}{l}++ \text { to }+ \\
++\end{array}$ & atherosclerosis & none & $\begin{array}{l}\text { DIC lung, chronic cholecystitis, necrosis liver \& } \\
\text { spleen }\end{array}$ \\
\hline 2 & Mongrel & M & 13 & Heart & +++ & atherosclerosis & none & Chemodectoma heart \\
\hline 3 & Bull terrier & $\mathrm{F}$ & 11 & Heart & + & hyperplastic & none & $\begin{array}{l}\text { Amyloidosis kidney, liver, spleen, heart \& } \\
\text { intestine }\end{array}$ \\
\hline 4 & Neapolitan Mastiff & $M C$ & 4 & Heart & + to ++ & hyperplastic & none & Glomerulonephritis, heart infarct \\
\hline 5 & Dachshund & M & 17 & Heart & + to ++ & hyperplastic & none & Endocardiosis AV valves \\
\hline 6 & St. Bernard & M & 4 & Heart & ++ & hyperplastic & none & Dilatative cardio-myopathy \\
\hline 7 & Mongrel & $M C$ & 11 & Heart & ++ & hyperplastic & lung, kidney & $\begin{array}{l}\text { Chronic lung hyper-tension, chronic interstitial } \\
\text { nephritis }\end{array}$ \\
\hline 8 & Scottish terrier & $\mathrm{F}$ & 12 & Heart & $\begin{array}{l}++ \text { to }+ \\
++\end{array}$ & hyperplastic & none & Hepatoma liver \\
\hline 9 & Golden Retriever & FC & 12 & Heart & $\begin{array}{l}++ \text { to }+ \\
++\end{array}$ & hyperplastic & none & Intestinal lymphoma \\
\hline 10 & $\begin{array}{l}\text { Bernese mountain } \\
\text { dog }\end{array}$ & $\mathrm{F}$ & 2 & Heart & + to ++ & $\begin{array}{l}\text { hyperplastic and } \\
\text { hyaline }\end{array}$ & none & $\begin{array}{l}\text { Chronic glomerulo-nephritis \& interstitial } \\
\text { nephritis }\end{array}$ \\
\hline 11 & $\begin{array}{l}\text { Large } \\
\text { Münsterländer }\end{array}$ & $\mathrm{F}$ & 13 & Heart & ++ & $\begin{array}{l}\text { hyperplastic and } \\
\text { hyaline }\end{array}$ & none & Hemangiosarcoma heart \& kidney \\
\hline 12 & Jack Russel terrier & $\mathrm{F}$ & 11 & Heart & $\begin{array}{l}++ \text { to }+ \\
++\end{array}$ & $\begin{array}{l}\text { hyperplastic and } \\
\text { hyaline }\end{array}$ & none & Myocardial fibrosis \& AV endocardiosis left \\
\hline 13 & German shepherd & M & 13 & Heart & +++ & $\begin{array}{l}\text { hyperplastic and } \\
\text { hyaline }\end{array}$ & none & endocardiosis AV left \& Aortic valves \\
\hline 14 & $\begin{array}{l}\text { Bernese mountain } \\
\text { dog }\end{array}$ & M & 9 & Heart & +++ & $\begin{array}{l}\text { hyperplastic and } \\
\text { hyaline }\end{array}$ & none & Hemangiosarcoma kidney \\
\hline 15 & Dobermann & $\mathrm{F}$ & 11 & Heart & $\begin{array}{l}++ \text { to }+ \\
++\end{array}$ & hyaline & none & Chronic interstitial nephritis \\
\hline 16 & Manchester terrier & FC & 13 & Aorta & ++ & hyaline & none & Glomerulonephritis \\
\hline
\end{tabular}

+ mild; ++ moderate; +++ severe; - not present

AV, Atrioventricular; M, Male; F, Female; MC, Male Castrated, FC, Female Castrated; 
Macroscopic and microscopic examples of atherosclerotic changes in the coronary arteries of the heart of dog no 2 are shown in Figure 1 and 2a, respectively. Higher magnification of the atherosclerotic lesion of case no. 2 is shown in Figure 2b. The most common type of arteriosclerotic lesions in the coronary arteries was hyperplastic ( $n=12$, Figure 3$)$, occurring either alone $(n=7 /$ 12) or in combination with hyaline arteriosclerosis $(\mathrm{n}=$ $5 / 7$, Figure 4$)$. The grade of all lesions $(n=16)$ varied from mild to severe in all possible combinations, with moderate to severe as the most common (31.3\%). Lumen narrowing was present in 15 cases (93.8\%), followed by thrombosis in seven cases $(43.8 \%)$, vessel wall edema $(\mathrm{n}=3,18.8 \%)$, and degeneration of leiomyocytes ( $\mathrm{n}=2,12.5 \%)$.

\section{Cats}

Arteriosclerosis was present in all 13 cat hearts, as evident in Table 2. None of these cases showed atherosclerotic lesions. The most frequent type of arteriosclerotic lesions was hyperplastic arteriosclerosis, occurring either alone $(\mathrm{n}=9,69.2 \%)$ or in combination with hyaline arteriosclerosis $(n=11,84.6 \%)$. The grade

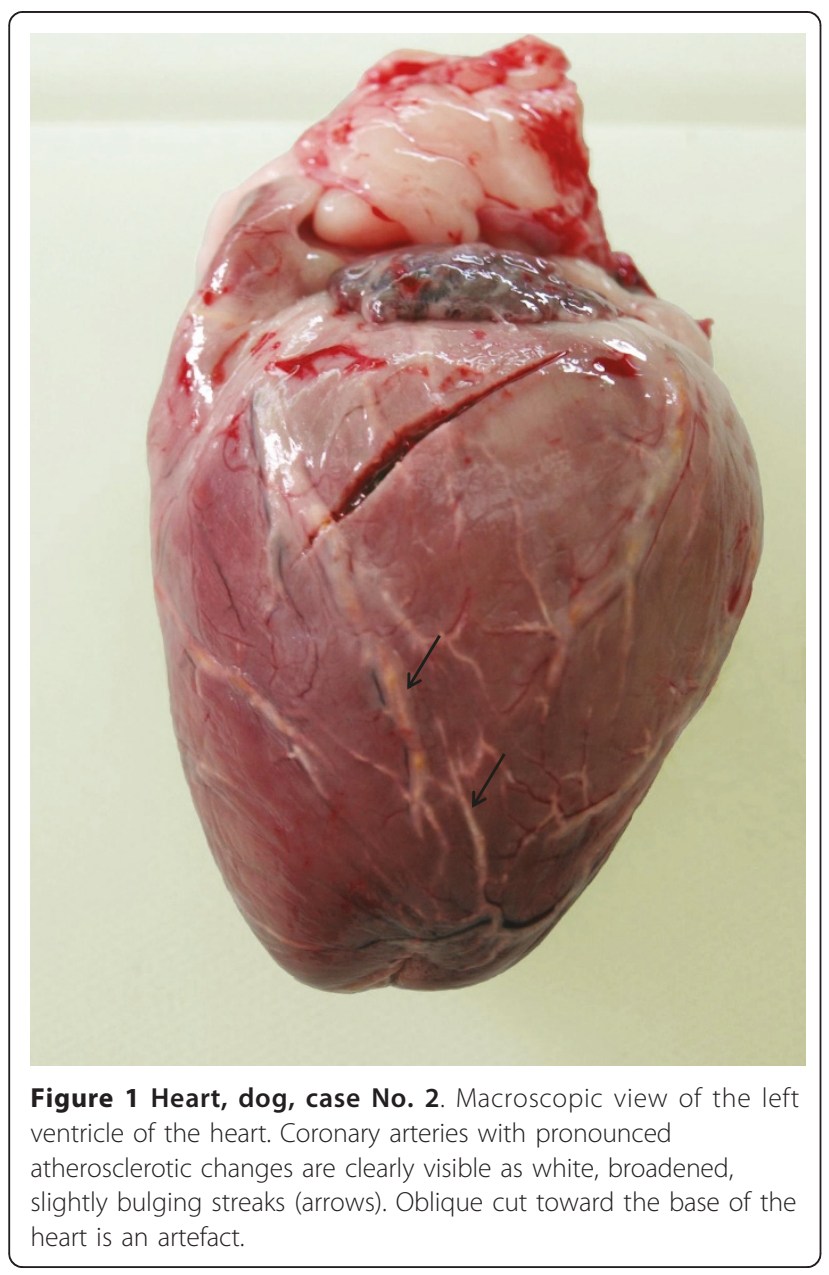

of all lesions again varied from mild to severe in all possible combinations, with moderate as the most common (53.8\%). Lumen narrowing was observed in 12 cases (92.3\%), followed by degeneration of leiomyocytes and vessel wall edema in four $(30.8 \%)$, and thrombosis in three cases (23.1\%).

\section{Chlamydiaceae real-time PCR}

Of all the samples (hearts and other organs affected in these animals, $n=45$ ), only one was considered questionably positive by real-time PCR (with a Ct value of 38.5). This questionably positive sample was from a cat heart (case no. 3).

\section{ArrayTube (AT) Microarray for species identification of Chlamydiaceae}

The only questionably positive sample by real-time PCR (cat case no. 3) was investigated by the species-specific 23S AT Microarray, and the presence of C. abortus specific DNA was detected in the sample.

\section{Immunohistochemistry (IHC)}

No positive labelling was observed in the feline heart tissue of the only Chlamydiaceae real-time PCR questionable case positive by AT Microarray for C. abortus (cat case no. 3).

\section{Discussion}

The aim of this study was to correlate spontaneous atherosclerotic and arteriosclerotic lesions in heart tissues of dogs and cats with the presence of Chlamydia. Regarding solely atherosclerotic cases, no connection was established between these lesions and chlamydial infections. However, it was not possible to draw final conclusions from these results, since there were only two cases showing atherosclerotic changes. These findings are contrary to those from a similar study [16] in which the authors found the presence of C. psittaci and C. pneumoniae in all seven canine atherosclerotic cases investigated in the study by using immunohistochemical methods. They subsequently confirmed their findings by conducting a C. pneumoniae-specific PCR in one of these cases, which yielded a positive result. They also identified Chlamydia in an unspecified number of cases using electron microscopy. In the present study, a different diagnostic approach was chosen. As it has been postulated that immunohistochemistry can yield false positive results due to a cross-reaction of chlamydial antibodies with microcalcifications and insoluble lipid ceroids, a two-step approach was applied here with initial screening by real-time PCR for Chlamydiaceae followed by the ArrayTube Microarray and immunohistochemistry [14]. This combination of methodologies was advised for the identification of Chlamydia in 


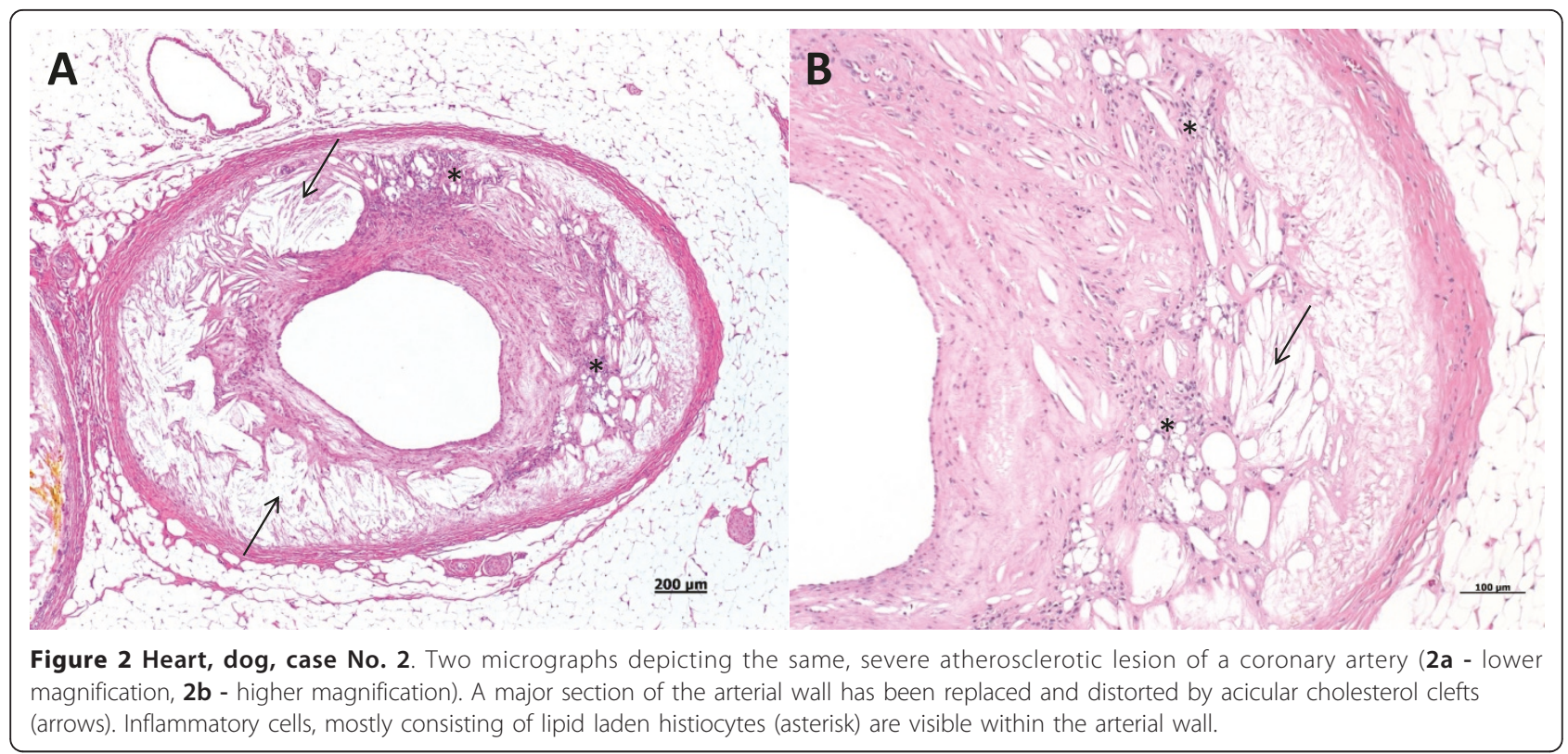

animal tissue samples in a recent review paper [22]. The different diagnostic approach and the low number of atherosclerosis cases could explain the different results when comparing this study with the study by Sako et al., 2002 [16]. Considering the latter, it would be highly advisable in any future studies that a larger number of atherosclerotic cases be examined.

On account of the very low number of coronary atherosclerosis cases in dogs and cats yielded by the database search, coronary arteriosclerotic cases were included in this study. To date, there are no reports in veterinary

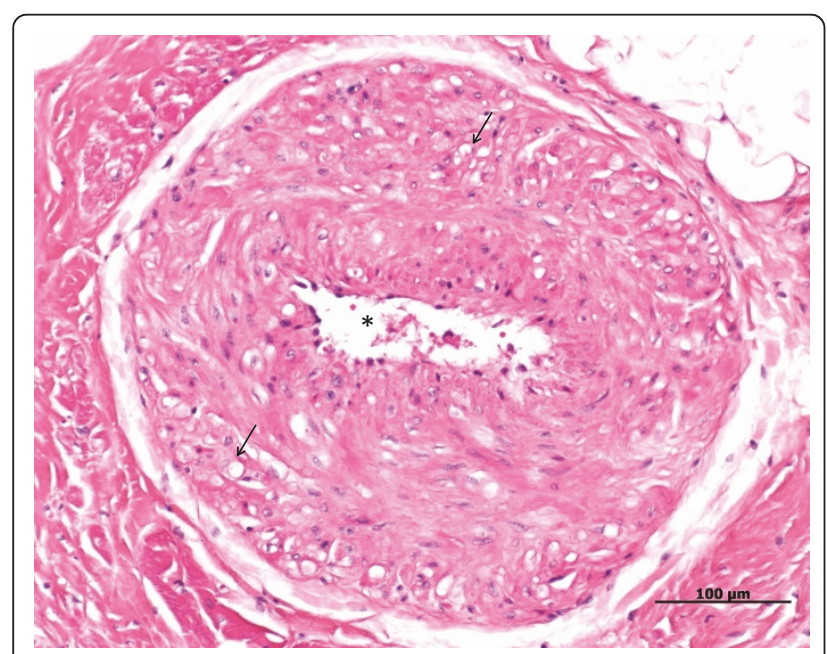

Figure 3 Heart, dog, case No. 9. Hyperplastic arteriosclerosis of a branch of coronary artery. Note the thickened vessel wall and extremely narrowed lumen (asterisk). In addition to being hyperplastic, some leiomyocytes of the vessel wall are also degenerated, seen by the clear vacuoles in the cytoplasm (arrows). medicine linking arteriosclerosis with the presence of Chlamydia. However, in human medicine there is a publication indicating an association between the presence of C. pneumoniae and early calcification of the tunica media in arteriosclerotic coronary arteries [23]. Thus, it seemed worthwhile to investigate coronary arteriosclerotic lesions from dogs and cats. In conclusion, examination of arteriosclerotic lesions in 14 dogs and 13 cats, did not reveal any presence of Chlamydia in dogs, and found only one positive case in a cat. This low incidence of positive cases indicated that chlamydial

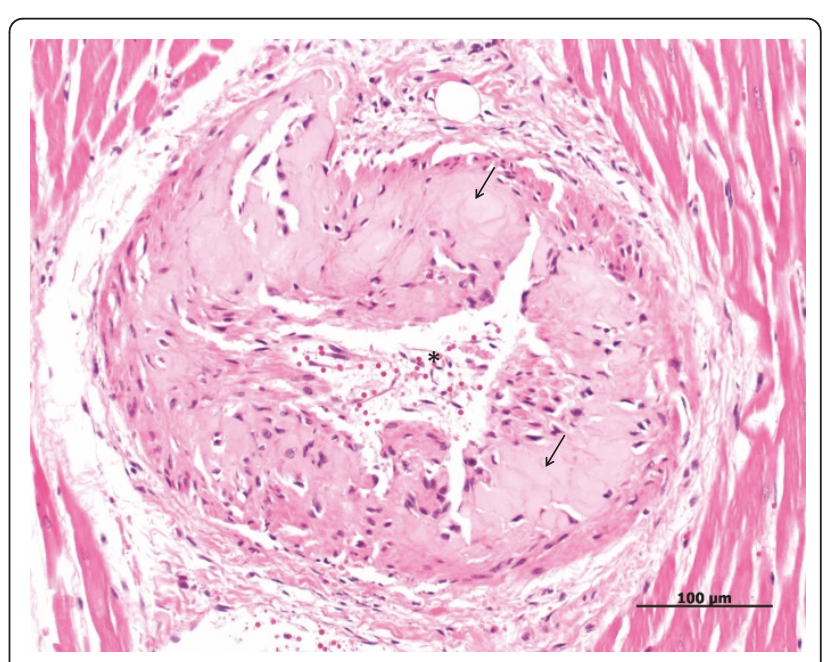

Figure 4 Heart, dog, case No. 15. Hyaline arteriosclerosis of a branch of the coronary artery. Note the irregular and narrowed lumen of the artery (asterisk). Acellular areas with an accumulation of eosinophilic, lightly translucent, protein like (hyaline) material (arrows) are visible in the vessel wall. 
Table 2 Type and grade of arteriosclerotic lesions in hearts of cats $(n=13)$

\begin{tabular}{|c|c|c|c|c|c|c|c|c|}
\hline No & Breed & Sex & Age & Organ & Grade & Type & Other organs affected & $\begin{array}{l}\text { Concurrent lesions in the heart or other } \\
\text { organs }\end{array}$ \\
\hline 1 & Persian cat & MC & 8 & Heart & + & hyperplastic & none & $\begin{array}{l}\text { Dilatative cardio-myopathy, chronic interstitial } \\
\text { nephritis }\end{array}$ \\
\hline 2 & $\begin{array}{l}\text { European } \\
\text { shorthair }\end{array}$ & FC & 8 & Heart & $\begin{array}{l}+ \text { to }+ \\
+\end{array}$ & hyperplastic & none & Chronic interstitial nephritis \\
\hline 3 & $\begin{array}{l}\text { European } \\
\text { shorthair }\end{array}$ & FC & $?$ & Heart & $\begin{array}{l}+ \text { to }+ \\
+\end{array}$ & hyperplastic & liver, kidney, spleen & $\begin{array}{l}\text { Chronic interstitial nephritis, hypertensive } \\
\text { retinopathy }\end{array}$ \\
\hline 4 & $\begin{array}{l}\text { European } \\
\text { shorthair }\end{array}$ & MC & 12 & Heart & ++ & hyperplastic & none & Chronic interstitial nephritis, heart infarcts \\
\hline 5 & $\begin{array}{l}\text { European } \\
\text { shorthair }\end{array}$ & $\mathrm{F}$ & $?$ & Heart & ++ & hyperplastic & none & Fibrosis of the atrio-ventricular node \\
\hline 6 & $\begin{array}{l}\text { European } \\
\text { shorthair }\end{array}$ & $\mathrm{F}$ & 15 & Heart & ++ & hyperplastic & kidney, eye, brain & $\begin{array}{l}\text { Hypertrophic cardio-myopathy, glomerulo- } \\
\text { nephritis }\end{array}$ \\
\hline 7 & $\begin{array}{l}\text { British } \\
\text { shorthair }\end{array}$ & MC & 5 & Heart & ++ & hyperplastic & none & Left ventricular hyper-trophy, myocardial fibrosis \\
\hline 8 & $\begin{array}{l}\text { European } \\
\text { shorthair }\end{array}$ & FC & 15 & Heart & ++ & hyperplastic & eye & $\begin{array}{l}\text { Thyroid adenoma, hypertrophic cardio-myopathy, } \\
\text { chronic interstitial nephritis }\end{array}$ \\
\hline 9 & $\begin{array}{l}\text { European } \\
\text { shorthair }\end{array}$ & FC & 6 & Heart & $\begin{array}{l}++ \text { to } \\
+++\end{array}$ & hyperplastic & none & Chylothorax, myocardial fibrosis \& necrosis \\
\hline 10 & $\begin{array}{l}\text { European } \\
\text { shorthair }\end{array}$ & $\mathrm{F}$ & 13 & Heart & ++ & $\begin{array}{l}\text { hyperplastic } \\
\text { and hyaline }\end{array}$ & $\begin{array}{l}\text { spleen, kidney, stomach, heart, } \\
\text { meninges, eyes }\end{array}$ & Chronic interstitial nephritis \\
\hline 11 & $\begin{array}{l}\text { European } \\
\text { shorthair }\end{array}$ & M & 1 & Heart & +++ & $\begin{array}{l}\text { hyperplastic } \\
\text { and hyaline }\end{array}$ & kidney & $\begin{array}{l}\text { Hypertrophic cardio-myopathy, chronic interstitial } \\
\text { nephritis }\end{array}$ \\
\hline 12 & Burmese cat & $M C$ & 16 & Heart & ++ & hyaline & brain & $\begin{array}{l}\text { Hypertrophic cardio-myopathy, chronic interstitial } \\
\text { nephritis }\end{array}$ \\
\hline 13 & Birman & FC & 1.5 & Heart & +++ & hyaline & none & Brain edema \\
\hline
\end{tabular}

+ mild; ++ moderate; +++ severe; - not present

M, Male; F, Female; MC, Male Castrated, FC, Female Castrated;

infections are not directly linked to the development of canine and feline arteriosclerotic lesions. In general, reports on chlamydial infections in dogs of Switzerland are scarce, and are either case reports of C. abortus induced keratoconjunctivitis, or studies that failed to prove the presence of Chlamydia in dogs with or without idiopathic pericardial effusion [24,25]. This lack of data could either be due to a low prevalence of canine chlamydial infections in this country or due to limited investigations on this animal species. Considering the data from other countries, Holst et al., 2010 found no Chlamydia from the ocular or genital swabs of healthy Swedish dogs or those showing genital or ocular clinical signs, indicating either a low prevalence or absence of chlamydial infections in these animals [26]. However, there are previous reports of Chlamydia-associated disease in dogs. C. psittaci in dogs can cause respiratory disease, conjunctivitis and listlessness $[27,28]$.

When comparing the situation in cats, it is well known that Chlamydia is considered a cause of ocular disease in cats worldwide, including Switzerland [29,30]. Therefore Chlamydia is more likely to be found in association with cats than it is with dogs. The present results, however, do not point in this direction, since only one Chlamydia-positive case was found in coronary arteriosclerotic samples from cats. In older studies, $C$. psittaci (old classification) was implicated as an etiologic agent of pneumonia in cats [31,32]. As such, a parallel with the development of human atherosclerosis, where C. pneumoniae is thought to travel from the patient's lung to coronary arteries (proven in a murine model), could have been proposed [33]. However, these speculations are no longer relevant for the pathogenesis of atherosclerosis and Chlamydia in cats as newer reports indicate that Chlamydia is not involved in feline pneumonia [34].

The chlamydial species in the only positive feline case was neither C. pneumoniae, the most common chlamydial species involved in human cardiovascular lesions, nor C. felis, a recognized pathogen of feline conjunctivitis, but instead was C. abortus $[29,35]$. This chlamydial species is known worldwide as a cause of abortions in ruminants - e.g. ovine enzootic abortion in sheep, but has not previously been described in cats [36]. The occurrence of a particular chlamydial species in another host was already implicated in the work of Pantchev et al., 2010, showing that the host range of a particular chlamydial species is not as strict as previously thought 
[35]. Thus, more research should be conducted in identifying the possible range of chlamydial species in various chlamydial diseases and different hosts.

The very low number of atherosclerotic cases recorded during more than 20 years of necropsies (7,057 necropsies of dogs, and 8,601 necropsies of cats) showed the low incidence of this condition in dogs $(\mathrm{n}=2 ; 0.028 \%)$, and absence of the condition in cats $(\mathrm{n}=0)$. Likewise, the total number of arteriosclerotic lesions in dogs $(\mathrm{n}=$ $14 ; 0.2 \%)$ and cats $(\mathrm{n}=13 ; 0.15 \%)$ was quite low for such a long period, which could imply that arteriosclerosis does not play a very important role in the development of heart pathologic conditions in these species. The literature search did not yield any reports on the incidence of canine or feline coronary arteriosclerosis that would support the present findings. According to textbooks, arteriosclerosis is quite common in older dogs and cats and it has the potential to cause coronary ischemia, but not very often [18].

The present results on the histopathological classification of arteriosclerotic lesions showed similarities between the distribution of lesions according to arteriosclerosis grade and type between dogs and cats. However, $46.2 \%$ of cats were found to have simultaneous coronary and extracoronary lesions, as compared to only $6.2 \%$ of such cases in dogs. Thus, arteriosclerosis seems to be a more systemic disease in cats, and is not strictly associated with the heart. One explanation for this could be that in many selected feline cases, interstitial nephritis was also present (data not shown). Thus, severe interstitial nephritis may have caused end stage kidney and renal failure, which is known to cause hypertension that in turn leads to arteriosclerotic changes first in renal arteries and then systemic [18].

\section{Conclusions}

In conclusion, this investigation indicates that there is no obvious correlation between spontaneous coronary arteriosclerotic lesions of dogs and cats and chlamydial infections. Regarding the association of Chlamydia and atherosclerosis, more samples of canine and feline atherosclerotic lesions should be investigated to draw final conclusions on the relevance of Chlamydia as an inducer or bystander of such lesions.

\footnotetext{
Acknowledgements

The authors thank Dr. Paula Grest for conducting the Institute's database search and Dr. Maja Rutten for help with image computer editing. The authors would also like to thank the laboratory technicians of the laboratory of the Institute of Veterinary Pathology, Zurich for preparing the sections. The first author was granted by Federal Commission for Scholarships for Foreign Students (FCS), Switzerland.
}

\section{Author details}

${ }^{1}$ Department of Veterinary Pathology, Veterinary Faculty, University of Zagreb, Heinzelova 55, 10000 Zagreb, Croatia. ${ }^{2}$ Institute for Veterinary
Pathology, University of Zurich, Vetsuisse Faculty, Winterthurerstrasse 268, $\mathrm{CH}-8057$ Zurich, Switzerland.

\section{Authors' contributions}

ICSZ conducted most of the laboratory work, performed the light microscopy and drafted the manuscript. NB devised the design of the study, participated in drafting of the manuscript and assisted with light microscopy. CK participated in laboratory work. ZG and AP participated in design of the study and contributed to writing the manuscript. All authors read and approved the final version of the manuscript.

\section{Declaration of competing interests}

The authors declare that they have no competing interests.

Received: 7 July 2011 Accepted: 9 September 2011

Published: 9 September 2011

\section{References}

1. The world health report 2004 - changing history, World Health Organization. [http://www.who.int/whr/2004/annex/topic/en/annex_2_en. pdf], "Annex Table 2: Deaths by cause, sex and mortality stratum in WHO regions, estimates for 2002".

2. Ross R: Atherosclerosis is an inflammatory disease. Am Heart J 1999, 138:419-420.

3. Niccoli G, Franceschi F, Cosentino N, Giupponi B, De Marco G, Merra G, Conte M, Montone RA, Ferrante G, Bacà M, Gasbarrini A, Silveri NG, Crea F: Coronary atherosclerotic burden in patients with infection by CagApositive strains of Helicobacter pylori. Coron Artery Dis 2010, 21(4):217-221.

4. Nicholson AC, Hajjar DP: Herpesvirus in atherosclerosis and thrombosis: etiologic agents or ubiquitous bystanders? Arterioscler Thromb 1998, 18(3):339-348

5. Watson C, Alp NJ: Role of Chlamydia pneumoniae in atherosclerosis. Clin Sci (Lond) 2008, 114:509-531.

6. Saikku P: Seroepidemiology in Chlamydia pneumoniae - atherosclerosis association. Eur Heart J 2002, 23(4):263-4.

7. Ramirez JA: Isolation of Chlamydia pneumoniae from the coronary artery of a patient with coronary atherosclerosis. The Chlamydia pneumoniae/ Atherosclerosis Study Group. Ann Intern Med 1996, 125(12):979-82.

8. Boman J, Hammerschlag MR: Chlamydia pneumoniae and atherosclerosis: critical assessment of diagnostic methods and relevance to treatment studies. J Clin Microbiol 2002, 15(1):1-20.

9. Borel N, Summersgill JT, Mukhopadhyay S, Miller RD, Ramirez JA, Pospischil A: Evidence for persistent Chlamydia pneumoniae infection of human coronary atheromas. Atherosclerosis 2008, 199(1):154-161.

10. Lajunen T, Vikatmaa P, Ikonen $T$, Lepäntalo M, Lounatmaa K, Sormunen R, Rantala A, Leinonen M, Saikku P: Comparison of polymerase chain reaction methods, in situ hybridization, and enzyme immunoassay for detection of Chlamydia pneumoniae in atherosclerotic carotid plaques. Diagn Microbiol Infect Dis 2008, 61(2):156-164.

11. Kuo CC, Gown AM, Benditt EP, Grayston JT: Detection of Chlamydia pneumoniae in aortic lesions of atherosclerosis by immunocytochemical stain. Arterioscler Thromb 1993, 13(10):1501-1504.

12. Borel N, Mukhopadhyay S, Kaiser C, Sullivan ED, Miller RD, Timms P, Summersgill JT, Ramirez JA, Pospischil A: Tissue Microarray (TMA) analysis of normal and persistent Chlamydophila pneumoniae infection. BMC Infect Dis 2006, 6:152.

13. Grayston JT, Kuo CC, Coulson AS, Campbell LA, Lawrence RD, Lee MJ, Strandness ED, Wang SP: Chlamydia pneumoniae (TWAR) in atherosclerosis of the carotid artery. Circulation 1995, 92(12):3397-3400

14. leven MM, Hoymans VY: Involvement of Chlamydia pneumoniae in atherosclerosis: more evidence for lack of evidence. J Clin Microbiol 2005, 43(1):19-24.

15. Hess RS, Kass PH, Van Winkle TJ: Association between diabetes mellitus, hypothyroidism or hyperadrenocorticism, and atherosclerosis in dogs. $J$ Vet Intern Med 2003, 17:489-494.

16. Sako T, Takahashi T, Takehana K, Uchida E, Nakade T, Umemura T, Taniyama H: Chlamydial infection in canine atherosclerotic lesions. Atherosclerosis 2002, 162(2):253-9.

17. Mitchell RN, Schoen FJ: Blood vessels. In Pathologic Basis of Disease.. 8 edition. Edited by: Kumar V, Abbas AK, Fausto N, Aster JC. Philadelphia, USA: Saunders Elsevier; 2010:487-528. 
18. Grant Maxie M, Robinson WF: Cardiovascular system. In Jubb, Kennedy, and Palmer's Pathology of Domestic Animals. Volume 3.. 5 edition. Edited by: Grant Maxie M. Philadelphia, USA: Saunders Elsevier; 2007:1-105.

19. Ehricht R, Slickers P, Goellner S, Hotzel H, Sachse K: Optimized DNA Microarray assay allows detection and genotyping of single PCRamplifiable target copies. Mol Cell Probes 2006, 20:60-63.

20. Borel N, Kempf E, Hotzel H, Schubert E, Torgerson P, Slickers P, Ehricht R, Tasara T, Pospischil A, Sachse K: Direct identification of chlamydiae from clinical samples using a DNA Microarray assay - A validation study. $\mathrm{Mol}$ Cell Probes 2008, 22:55-64.

21. Guscetti F, Hoop R, Schiller I, Corboz L, Sydler T, Pospischill A: Experimental enteric infection of gnotobiotic piglets with Chlamydia psittaci strain of avian origin. J Vet Med B 2000, 47:561-572.

22. Sachse K, Vretou E, Livingstone M, Borel N, Pospischil A, Longbottom D: Recent developments in the laboratory diagnosis of chlamydial infections. Vet Microbiol 2009, 135(1-2):2-21.

23. Bobryshev YV, Lord RS, Tran D: Chlamydia pneumoniae in foci of "early" calcification of the tunica media in arteriosclerotic arteries: an incidental presence? Am J Physiol Heart Circ Physiol 2006, 290(4):1510-1519.

24. Hoelzle K, Wittenbrink MM, Corboz L, Hoelzle LE: Chlamydophila abortusinduced keratoconjunctivitis in a dog. Vet Rec 2005, 157(20):632-633.

25. Zini E, Glaus TM, Bussadori C, Borgarelli M, Santilli RA, Tarducci A, Margiocco ML, Rampazzo A, Meli ML, Maisch B, Pankuweit S: Evaluation of the presence of selected viral and bacterial nucleic acids in pericardial samples from dogs with or without idiopathic pericardial effusion. Vet $J$ 2009, 179(2):225-229.

26. Holst BS, Hanls S, Bölske G, Forsberg CL: An investigation on the presence of Chlamydiaceae in Swedish dogs. Acta Vet Scand 2010, 16:52-63.

27. Sprague LD, Schubert E, Hotzel H, Scharf S, Sachse K: The detection of Chlamydophila psittaci genotype C infection in dogs. Vet J 2009, 181(3):274-279.

28. Gresham AC, Dixon CE, Bevan BJ: Domiciliary outbreak of psittacosis in dogs: potential for zoonotic infection. Vet Rec 1996, 138(25):622-623

29. Sykes JE: Feline chlamydiosis. Clin Tech Small Anim Pract 2005, 20(2):129-34

30. von Bomhard W, Polkinghorne A, Lu ZH, Vaughan L, Vögtlin A, Zimmermann DR, Spiess B, Pospischil A: Detection of novel chlamydiae in cats with ocular disease. Am J Vet Res 2003, 64(11):1421-1428.

31. Baker JA: A virus causing pneumonia in cats and producing elementary bodies. J Exp Med 1944, 79:159-72.

32. Hoover EA, Kahn DE, Langloss JM: Experimentally induced feline chlamydial infection (feline pneumonitis). Am J Vet Res 1978, 39:541-547.

33. Yang ZP, Kuo CC, Grayston JT: Systemic dissemination of Chlamydia pneumoniae following intranasal inoculation in mice. J Infect Dis 1995, 171(3):736-738.

34. Bart M, Guscetti F, Zurbriggen A, Pospischil A, Schiller I: Feline Infectious Pneumonia: A Short Literature Review and a Retrospective Immunohistological Study on the Involvement of Chlamydia spp. and Distemper Virus. Vet J 2000, 159(3):220-230.

35. Pantchev A, Sting R, Bauerfeind R, Tyczka J, Sachse K: Detection of all Chlamydophila and Chlamydia spp. of veterinary interest using speciesspecific real-time PCR assays. Comp Immunol Microbiol Infect Dis 2010, 33(6):473-84.

36. Longbottom D, Coulter LJ: Animal chlamydioses and zoonotic implications. J Comp Pathol 2003, 128(4):217-244.

\section{Submit your next manuscript to BioMed Central and take full advantage of:}

- Convenient online submission

- Thorough peer review

- No space constraints or color figure charges

- Immediate publication on acceptance

- Inclusion in PubMed, CAS, Scopus and Google Scholar

- Research which is freely available for redistribution

Submit your manuscript at www.biomedcentral.com/submit
Biomed Central 